\title{
https://doi.org/10.48009/1_iis_2006_182-187 \\ ABET-CAC IS ACCREDITATION: CURRICULAR STANDARDS AND PROGRAM RANKINGS
}

\author{
Gary J. DeLorenzo, California University of Pennsylvania, delorenzo@cup.edu \\ Frederick G. Kohun, Robert Morris University, kohun@ rmu.edu \\ David F. Wood, Robert Morris University, wood@rmu.edu
}

\begin{abstract}
In the past four years, the total number of Information Systems (IS) programs attaining ABETCAC accreditation has grown to 15. As the number of IS programs seeking accreditation is likely to increase, there is a need to assess not only the gains associated with the accreditation process but also potential unplanned negatives. This paper frames the recent $A B E T$ accreditation model with respect to the balance between business and stand-alone IS programs. The data analyzed for this paper was restricted to the curriculum of the current 15 ABET$C A C$ accredited schools and the curriculum of the top 19 MIS programs as identified by a popular and frequently cited ranking system [1].
\end{abstract}

Keywords: ABET-CAC, MIS Programs, Accreditation, Information Systems

\section{INTRODUCTION}

Five years after the first accreditation of an Information Systems program, there are 15 Information Systems programs accredited by the Accreditation Board for Engineering and Technology-Computing Accreditation Commission (ABET-CAC) [1]. Early discussions on accreditation focused on standards, consistency, defining the discipline, and quality. The first formal attempt at this focus publicly culminated with the IS95 Model Curriculum. This curriculum not only included a rationale for an IS program with suggested courses, but also extensive mapping of course objectives, learning points, and learning outcomes [11]. The impact was significant and immediate. Now 11 years after that curriculum had been distributed and revised two times, it has become the foundation of the ABET-CAC accreditation that took form in 2002. However, with such a solid and welcomed acceptance, this curricular model evolved into the underlying foundation of accreditation standards. This paper initially presents a brief literature review that focuses on ABET-CAC curricular issues related to Information Systems programs. Then, a model of an information system is used to frame the ABETCAC program standards as juxtaposed to non-ABET program standards. A detailed overview of the common curricular components of the ABET-CAC is presented in the context of the top 19 rated MIS programs. Finally, innovation will be introduced as something that evolves and dominates outside of accreditation standards.

\section{BACKGROUND AND CONTEXT}

An analysis was performed of previous research by examining ABET IS accreditation in areas such as the value in receiving accreditation, the value in positioning the program in the school of business, and its relationship to AACSB accreditation. The review included an analysis of the prior work on ABET IS accreditation by Gorgone, Hilton, Jones, Lidtke, and MacKinnon. A synopsis of their findings is presented in Table 1 to support the position taken in this paper.

Table 1. Selected ABET-CAC Research Since 2001

\begin{tabular}{|l|l|}
\hline \multicolumn{1}{|c|}{ Researchers } & \multicolumn{1}{c|}{ Findings } \\
\hline Gorgone, J. et al. & 2002 revision of the IS 97 model curriculum [3]. \\
\hline $\begin{array}{l}\text { Lidke, D.K. and } \\
\text { Yaverbaum, G.J. }\end{array}$ & $\begin{array}{l}\text { Information Systems Programs, while still in Business Schools, are found in increasing } \\
\text { numbers in departments outside of business [10]. }\end{array}$ \\
\hline Hilton, T.S.E. & Most accredited IS programs are BS degrees, not bound by AACSB [3]. \\
\hline $\begin{array}{l}\text { Kohun, F.G., \& } \\
\text { Wood, D. F. }\end{array}$ & Accredited IS programs are not usually located in a College of Business [7]. \\
\hline $\begin{array}{l}\text { MacKinnon, R. J., } \\
\text { \& Butler, E. S. }\end{array}$ & $\begin{array}{l}\text { Accredited IS programs have replaced some typical business credits with additional IS } \\
\text { credits, thus producing a stronger technically oriented IS programs [12]. }\end{array}$ \\
\hline Hilton, T.S.E., & Until recently, AACSB programs did not list information systems as a required content area. \\
\hline
\end{tabular}




\begin{tabular}{|l|l|}
\hline \multicolumn{1}{|c|}{ Researchers } & \multicolumn{1}{c|}{ Findings } \\
\hline $\begin{array}{l}\text { Johnson, D. A., \& } \\
\text { Kasper, G. M. }\end{array}$ & $\begin{array}{l}\text { Information systems as a content area was absent from early AACSB accreditation standards, } \\
\text { but changes in 2003 approved a standard where curriculum includes information } \\
\text { technologies as they influence the structure and processes of organizations and economies } \\
\text { and the role and techniques of management [5]. }\end{array}$ \\
\hline Jones, C. G & $\begin{array}{l}\text { There is a significant difference in required information systems coursework between IS } \\
\text { programs housed in AACSB-accredited business schools and those housed in information } \\
\text { system schools [6]. }\end{array}$ \\
\hline $\begin{array}{l}\text { Kohun, F.G., \& } \\
\text { Wood, D. F. }\end{array}$ & $\begin{array}{l}\text { The first IS programs evaluated by ABET were evaluated by computer science professionals } \\
\text { accustomed to evaluating technically strong computer science programs. Therefore, } \\
\text { historically, a technically strong IS program would have a better chance of being accredited } \\
{[8] .}\end{array}$ \\
\hline
\end{tabular}

As noted by Hilton [4], MIS programs in a business school provide "business graduates with [adequate] education in a major change lever" and "to ensure that a large number of technology professionals are adequately educated in basic business concepts." ABET accreditation of an MIS department housed within a college of business would only increase the credibility and quality of both the department and the college. However, ABET IS accreditation presents curriculum challenges on the balance of business and IS courses for those programs seeking AACSB accreditation, as noted by Jones [6].

\section{ABET PROGRAM CURRICULUM AND NON- ABET PROGRAM CURRICULUM}

Ranking of any programs labeled as IS have been unavailable since 1995. However, ComputerWorld's ranking of IS programs in 1995 included largely MIS programs. Therefore, we chose the US News and World Report's list of the top 19 MIS programs in 2006 (see Table 2) and compared their programs to the IS2002 model curriculum courses [13].

For many years, one of the most fundamental models to describe an information system has been the "Five Component Framework", described

by David Kroenke: "Hardware, Software, Data, Procedures, and People" [9]. We investigated where in the curriculum these components are treated.

We would like to argue that the ABET model focuses on Hardware, Software, and Data, with a lesser degree of attention to people and procedures. While business courses are a required part of the ABET accreditation, since IS courses are not permitted to be counted as an IS Environment, there are no explicit requirements for IS related business courses in the information system environment. We itemized the required and elective courses from the 19 top MIS program rankings and categorized them by IS2002 required courses to which they correspond. They are presented in the Table 3.

Table 2. Top 19 MIS Programs from U.S. News and World Report 2006

\begin{tabular}{|c|l|}
\hline Rank & University / College \\
\hline 1 & Massachusetts Inst of Technology \\
\hline 2 & Carnegie Mellon University \\
\hline 3 & University of Texas-Austin \\
\hline 4 & University of Arizona (Eller) \\
\hline 5 & Univ of Minnesota-Twin Cities \\
\hline 6 & Univ of Maryland-College Park \\
\hline 7 A & University of Michigan-Ann Arbor \\
\hline $7 B$ & University of Pennsylvania \\
\hline 9 & New York University \\
\hline 10 & Georgia State University \\
\hline 11 & University of California-Berkeley \\
\hline 12 & Indiana University-Bloomington \\
\hline 13 & Bentley College \\
\hline 14 & Purdue Univ -West Lafayette \\
\hline 15 & Arizona State University \\
\hline 16A & University of Georgia \\
\hline 16B & University of Oklahoma \\
\hline 16C & University of Virginia \\
\hline 19 & University of Washington \\
\hline & \\
\hline
\end{tabular}


Table 3. IS2002 Courses in top 19 MIS Programs

\begin{tabular}{|l|c|}
\hline \multicolumn{1}{|c|}{ IS2002 Course Title } & $\begin{array}{c}\text { No of } \\
\text { Universities }\end{array}$ \\
\hline Analysis and Logical Design & 15 \\
\hline $\begin{array}{l}\text { Electronic Business Strategy, } \\
\text { Architecture, and Design }\end{array}$ & 15 \\
\hline Fundamentals of Info Systems & 6 \\
\hline Global and Ethical Issues & 4 \\
\hline $\begin{array}{l}\text { Information Systems Theory and } \\
\text { Practice }\end{array}$ & 2 \\
\hline $\begin{array}{l}\text { Information Technology Hardware } \\
\text { and Software }\end{array}$ & 2 \\
\hline Networks and Telecom & 11 \\
\hline $\begin{array}{l}\text { Physical Design and Implementation } \\
\text { in Emerging Environments }\end{array}$ & 14 \\
\hline $\begin{array}{l}\text { Physical Design and Implementation } \\
\text { with DBMS }\end{array}$ & 16 \\
\hline $\begin{array}{l}\text { Programming, Data, File and Object } \\
\text { Structures }\end{array}$ & 15 \\
\hline Project Management and Practice & 8 \\
\hline
\end{tabular}

It can be seen from Table 3 that none of the top 19 programs include all of the IS2002 courses. This is made more noticeable when noting that this table includes not only required courses but also possible electives. Only 5 of the 10 courses are included by over $70 \%$ of the top 19 programs. The five courses include Analysis and Logical Design, Electronic Business Strategy, Architecture, and Design, Physical Design in Emerging Environments, Physical Design and Implementation with DBMS, and Programming, Data, File, and Object Structures. Many universities required programming courses to be taken outside the MIS department in a Computer Science department. It seems that MIS programs emphasize the Systems Development Life Cycle with few electives in other areas. A significant discovery was how few institutions even offered courses in Information Technology Hardware and Software, and Information Systems Theory and Practice.

We categorized the IS2002 curriculum, labeling eBusiness Strategy, Analysis and Design, and Project Management as People and Procedure related courses. Based on our categorization, we found the top 19 MIS programs to emphasize Procedures and People and Data in their courses and a lesser degree of attention on hardware and software. This is consistent with the findings of Jones [6]:

“..., an AACSB IS program will include 17.2 hours of additional business course work. This business depth comes at the expense of information systems coursework depth. IS departments in AACSB schools will likely face a tradeoff of information systems coursework for business classes..."

However, these programs included many more courses. The extra courses covered a broad range of topics, including many innovative ones. Table 4 shows those universities listed in Table 2 where courses did not map to any IS2002 model curriculum course.

Table 4. Top 19 MIS Program Courses not Included in IS2002 Curriculum

\begin{tabular}{|c|c|}
\hline Course Title & University \\
\hline Advanced Net-Centric Computing & 13 \\
\hline Business Intelligence & $16 \mathrm{~A}$ \\
\hline Collaboration Computing & 4 \\
\hline $\begin{array}{l}\text { Complex Technological Systems: } \\
\text { Past, Present, and Future }\end{array}$ & 2 \\
\hline Data Mining & 3 \\
\hline Data Warehousing & 5 \\
\hline Directed Reading in MIS & $16 \mathrm{~B}$ \\
\hline $\begin{array}{l}\text { Economics and Psychology or } \\
\text { Organizational Communication }\end{array}$ & 2 \\
\hline $\begin{array}{l}\text { Economics of Entrepreneurship in } \\
\text { High Tech Industries }\end{array}$ & 2 \\
\hline Economics of Technological Change & 2 \\
\hline $\begin{array}{l}\text { Expert Systems / Artificial } \\
\text { Intelligence }\end{array}$ & $16 \mathrm{~B}$ \\
\hline Group Support Systems & 16B \\
\hline Independent Study & 12 \\
\hline $\begin{array}{l}\text { Individual Perspectives on } \\
\text { Information Systems }\end{array}$ & 19 \\
\hline $\begin{array}{l}\text { Information Needs, Searching, and } \\
\text { Presentation }\end{array}$ & 19 \\
\hline Information Systems Applications & 2 \\
\hline $\begin{array}{l}\text { Information Systems Industry } \\
\text { Internship }\end{array}$ & 5 \\
\hline Information Systems Security & 12 \\
\hline Information Systems Special Topics & 5 \\
\hline $\begin{array}{l}\text { Information Technology and } \\
\text { Business Systems Consulting }\end{array}$ & $7 \mathrm{~A}$ \\
\hline Intelligent Systems & 10 \\
\hline Internship & 3 \\
\hline Introduction to Artificial Intelligence & 4 \\
\hline Introduction to Security and Privacy & 10 \\
\hline $\begin{array}{l}\text { Knowledge Management: Techniques } \\
\text { and Practices }\end{array}$ & 4 \\
\hline $\begin{array}{l}\text { Modeling and Data Mining with } \\
\text { Spreadsheets }\end{array}$ & 9 \\
\hline
\end{tabular}




\begin{tabular}{|l|c|}
\hline Course Title & University \\
\hline Organizational Communication & 2 \\
\hline Organizational Intelligence & 2 \\
\hline Research methods in Informatics & 19 \\
\hline Research Project in CIS & $7 \mathrm{~A}$ \\
\hline $\begin{array}{l}\text { Rise of Industrial Research and } \\
\text { Development }\end{array}$ & 2 \\
\hline $\begin{array}{l}\text { Science, Technology and Business in } \\
\text { US History }\end{array}$ & 2 \\
\hline $\begin{array}{l}\text { Selected Topics in Information } \\
\text { Systems }\end{array}$ & $16 \mathrm{C}$ \\
\hline Seminar in Decision Systems & $7 \mathrm{~B}$ \\
\hline $\begin{array}{l}\text { Software Agents and Multi-Agent } \\
\text { Systems }\end{array}$ & 4 \\
\hline Special Topics in MIS & 4 \\
\hline Special Topics in MIS & $16 \mathrm{~A}$ \\
\hline Streaming Media & 9 \\
\hline Systems Modeling and Simulation & 4 \\
\hline The Software Business & 1 \\
\hline Topics in MIS & $16 \mathrm{~B}$ \\
\hline
\end{tabular}

\section{ACCREDITATION AND CHANGE}

The courses of IS2002, which embodied people and procedures to the largest extent, were that of Electronic Business Strategy, Architecture, and Design, and Analysis and Logical Design. Table 5 shows those universities listed in Table 2 where the top 19 MIS programs incorporated a great variety of courses within this area.

Table 5. People and Procedures Courses in Top 19 MIS Schools

\begin{tabular}{|l|c|}
\hline Course Title & University \\
\hline \multicolumn{2}{|c|}{$\begin{array}{c}\text { Electronic Business Strategy, } \\
\text { Architecture, and Design }\end{array}$} \\
\hline $\begin{array}{l}\text { Advanced Topics in Information } \\
\text { Strategy and Economics }\end{array}$ & $7 \mathrm{~B}$ \\
\hline Bus Proc \& Comm Infrastructure & 13 \\
\hline Business Process Excellence & 3 \\
\hline Business Process management & $16 \mathrm{~A}$ \\
\hline $\begin{array}{l}\text { Business Process Management } \\
\text { Systems }\end{array}$ & 4 \\
\hline Computer Utilization in Business & 3 \\
\hline Decision Processes & $7 \mathrm{~B}$ \\
\hline Decision Support Systems & $7 \mathrm{~B}$ \\
\hline Ecommerce & 6 \\
\hline E-Commerce Info Structure & 14 \\
\hline Economics of eCommerce & 2 \\
\hline
\end{tabular}

\begin{tabular}{|c|c|}
\hline Course Title & University \\
\hline \multirow{3}{*}{$\begin{array}{l}\text { Electronic Commerce } \\
\text { Electronic Commerce } \\
\text { Electronic Commerce }\end{array}$} & 9 \\
\hline & 5 \\
\hline & $16 \mathrm{C}$ \\
\hline Electronic Commerce & $16 \mathrm{~B}$ \\
\hline Electronic Commerce Strategy & 15 \\
\hline Enterprise Resource Planning & 12 \\
\hline Financial Information Systems & 9 \\
\hline $\begin{array}{l}\text { Financial Information Systems and } \\
\text { Technologies }\end{array}$ & 5 \\
\hline Financial Systems Engineering & $16 \mathrm{C}$ \\
\hline $\begin{array}{l}\text { Fundamentals of Digital Business } \\
\text { Strategy }\end{array}$ & 1 \\
\hline Info Systems Infrastructure & 16B \\
\hline $\begin{array}{l}\text { Information System Strategies for } \\
\text { E-commerce }\end{array}$ & 4 \\
\hline $\begin{array}{l}\text { Information Technology in } \\
\text { Business and Society }\end{array}$ & 9 \\
\hline $\begin{array}{l}\text { Integrated Enterprise Wide } \\
\text { Systems }\end{array}$ & $16 \mathrm{~A}$ \\
\hline Internet Business and Technology & 4 \\
\hline $\begin{array}{l}\text { Introduction to Enterprise } \\
\text { Computing Environments }\end{array}$ & 4 \\
\hline $\begin{array}{l}\text { IT Essentials II -- Advanced } \\
\text { Technologies for Digital Business } \\
\text { in the Knowledge Economy }\end{array}$ & 1 \\
\hline Managerial Decision Making & 2 \\
\hline Service Operations Management & $7 \mathrm{~B}$ \\
\hline Strategic IT management & 3 \\
\hline The Supply Chain and Logistics & 4 \\
\hline \multicolumn{2}{|c|}{ Analysis and Logical Design } \\
\hline $\begin{array}{l}\text { Analysis and Modeling for } \\
\text { Business Systems Development }\end{array}$ & 5 \\
\hline $\begin{array}{l}\text { Application Design and } \\
\text { Development }\end{array}$ & 2 \\
\hline Business Application Development & 12 \\
\hline Business Data Analysis & 16B \\
\hline Business Syst. Analysis \& Design & 13 \\
\hline $\begin{array}{l}\text { Enterprise Process Analysis and } \\
\text { Design }\end{array}$ & 15 \\
\hline $\begin{array}{l}\text { Human Interface to Information } \\
\text { Technology }\end{array}$ & $7 \mathrm{~A}$ \\
\hline Information System Design & 19 \\
\hline $\begin{array}{l}\text { Information Systems Analysis and } \\
\text { Design }\end{array}$ & 4 \\
\hline Object-Oriented Analysis \& Design & 14 \\
\hline Systems Analysis & 10 \\
\hline \multirow{4}{*}{$\begin{array}{l}\text { Systems Analysis \& Design } \\
\text { Systems Analysis \& Design } \\
\text { Systems Analysis \& Design } \\
\text { Systems Analysis \& Design }\end{array}$} & 6 \\
\hline & 9 \\
\hline & $16 \mathrm{~A}$ \\
\hline & 12 \\
\hline
\end{tabular}




\begin{tabular}{|l|c|}
\hline Course Title & University \\
\hline $\begin{array}{l}\text { Systems Analysis and Design } \\
\text { Theory }\end{array}$ & $16 \mathrm{~B}$ \\
\hline $\begin{array}{l}\text { Systems Analysis, Design, and } \\
\text { Implementation }\end{array}$ & $7 \mathrm{~B}$ \\
\hline Systems Design & 10 \\
\hline $\begin{array}{l}\text { Systems Design and Electronic } \\
\text { Commerce }\end{array}$ & 15 \\
\hline $\begin{array}{l}\text { User Interface design, Prototyping, } \\
\text { and Evaluation }\end{array}$ & 4 \\
\hline
\end{tabular}

Many of these courses lie in the nature of Business Process Management and Enterprise Systems Analysis. The nature of the standards in ABET, for example, make it very difficult to include them in accredited programs.

\section{FUTURE RESEARCH AND CONCLUSION}

To support the continuous improvement process for an institution's IS program, the ABET-CAC Board of Governors is pursing changes to improve the standards and criteria for IS accreditation including flexibility to adjust and adapt the curriculum. The direction appears to focus on the exploration of merging and emerging technologies for programs and disciplines such as biological engineering and the merging and emerging of disciplines themselves such as computer science and information systems [1]. This does not, however, remove the problem of public awareness regarding the nature and context of IS programs. It can be seen that none of the top 19 MIS programs fully encompass the ABET curriculum. This is, for the most, the result of other than ABET accreditation restrictions. Furthermore, because of ABET's historical engineering and science context, there has not been a focus to fully integrate business into the curriculum although there is requirement to have a number of stand-alone business courses.

Programs offered today may blend in the future and become more interdisciplinary where economic and market driven constraints, due to shrinking enrollments, may drive towards a "generalist" IS program. Courses on business, mathematics, science, social studies and communications will continue as prerequisites for IS programs, while higher level and capstone courses will concentrate on the integration of these courses through technology oriented courses in programming and analysis. To meet that evolution, ABET-CAC is currently revising its accreditation model into a more "outcome focused" process, thereby resulting in a more non-prescriptive curriculum criterion [1].

A pilot of the revised model will occur at selected institutions starting in Fall 2006. From the results on the pilot, ABET will either recommend the new, outcome based ABET-CAC accreditation model starting in Fall 2007 or revise the model with a targeted Fall 2008 startup date [2].

\section{REFERENCES}

1. ABET Computing Accreditation Commission (CAC) Computer Programs Forms and Criteria Retrieved March 12, 2006 from http://www.abet.org/forms.shtml

2. ABET Computing Accreditation Commission (CAC) Computer Science (CS) and Information System (IS) Evaluation Training Program, Houston, TX, March 4, 2006.

3. Gorgone, J.T, Davis, G.B., Valacich, J.S., Topi, H., Feinstein, D.L., Longenecker, H.E.Jr (2002). IS 2002: Model Curriculum and Guidelines for Undergraduate Degree Programs in Information Systems. Association for Information Systems, Atlanta, GA.

4. Hilton, T.S. E. (2003) MIS Program Accreditation: Comparing AACSB and ABET, ISECON 2003, 20

5. Hilton, T.S. E., Johnson, D. A., \& Kasper, G. M. (2004) ABET Accreditation of MIS Programs in AACSB Schools, ISECON 2004, 21, 1-16

6. Jones, C. G. (2004). An Analysis of Programmatic Differences Between Dual ABET/AACSB and ABET-Only Accredited Information Systems Programs, IACIS 2004, V2, 544-530.

7. Kohun, F.G., \& Wood, D. F. (2003). The ABET CAC Accreditation Experience - Intent and Reality - the Information Systems Perspective. Information Systems Education Journal, 1(43), 3-11

8. Kohun, F.G., \& Wood, D. F. (2004). The ABET CAC Accreditation - Is Accreditation Right for Information Systems? IACIS 2004, V2, 579-583

9. Kroenke, David (2007). Using MIS. Pearson Education. Upper Saddle River, NJ. p8

10. Lidtke, D.K. \& Yaverbaum, G.J. (2003). Developing Accreditation for Information Systems Education. IT Professional. 41-45.

11. Longenecker, H.E., Feinstein, D.L, Davis, G.B., Gorgone, J.T., Valacich, J. (2001). IS'2001: Progress Report on Updating IS'97', ISECON 2001 Conference Proceedings. 
12. MacKinnon, R. J., Butler, E. S. (2005). How Do IS Programs Compare With ABET Accredited Programs? IACIS 2004, V1, 332-338

13. U.S. News and World Report. America's Best Colleges 2006: Undergraduate Business Specialties: Management Information Systems.
Retrieved Feb 20, 2006 from http://www.usnews.com/usnews/edu/college/ran kings/premium/business/

bizspec03.php 